\title{
12. ENVIRONMENTAL LAW ISSUES IN THE SOUTH PACIFIC AND THE QUEST FOR SUSTAINABLE DEVELOPMENT AND GOOD GOVERNANCE
}

By: Laurence Cordonnery

\section{KEY TERMS AND PHRASES}

\section{Biodiversity}

Also referred to as biological diversity, biodiversity describes the variety and variability of nature. Plant and animal species are the most commonly recognised units of biological diversity.

\section{Sustainable development}

In 1987, the World Commission on Environment and Development (the Brundtland Commission) defined sustainable development as "development that meets the needs of the present without compromising the ability of future generations to meet their own needs." It requires an integration of economic, social and environmental considerations in decision making at both government and corporation levels in order to aim for development that does not rely upon the short term exploitaition of any resources.

\section{Environmental impact assessment (EIA)}

A critical appraisal of the likely effects of a policy, plan, program, project or activity on the environment. These assessments are usually carried out by independent assessors in order to assist the authority making the decision about whether to proceed with a particular activity.

\section{Good governance}

The term refers to a form of democratic governance that assumes legitimacy through accountability, predictability and openness of government formed by consent of the people and in accordance with the rule of law. In terms of resource allocation and acquisition, good governance presupposes consultation and participation of those affected by projects and transparency of decision making and resource allocation. 


\section{INTRODUCTION}

This chapter will introduce some of the environmental issues that need to be urgently addressed in the South Pacific. It focuses upon the issues that Pacific island countries (PICs) have some leverage in devising solutions for, whether within regional, national and/or local legal and management frameworks. In presenting current approaches to environmental protection and sustainable development the reasons why PICs should depart from a strict transposition of western legal models, the relevance of participatory democracy at the community level and the need for more transparency and accountability of state actions will be emphasised.

\section{THE MOST CRITICAL ENVIRONMENTAL ISSUES FOR THE SOUTH PACIFIC}

\section{Climate change}

Vulnerability to climate change and the resulting impacts on coastal environments due to sea level rise and coastal erosion, coral bleaching and changes in the productivity of marine ecosystems is certainly the most pressing environmental issue faced by PICs today, particularly for low-lying islands and atolls. Yet, despite general awareness of the issue at regional and governmental levels, any solution to climate change (as opposed to an adaptive reaction) will depend on the outcomes of the global negotiations on the implementation of the Kyoto Protocol to the United Nations Convention on Climate Change. To that extent, climate change remains an external issue for PICs despite them being its first victims. It can only be hoped that further regional solidarity will be demonstrated against the inflexibility of the JUSCAN group of countries (Japan, USA, Canada, Australia, and New Zealand) to effectively tackle the issue by accepting to reduce greenhouse gases emissions at their source. Typically, the example of climate change illustrates the lack of leverage of PICs to address this global issue. Because of the inability of PICs to be proactive in creating a solution to climate change this environmental threat will not be considered further in this chapter.

\section{The loss of biodiversity}

The loss of biodiversity, which mostly occurs through land degradation, is another pressing environmental issue of international relevance which has a better potential to be addressed within appropriate regional and national frameworks. This is because biodiversity loss is a direct result of population growth, urbanisation and unsustainable development activities within the region.

The tropical South Pacific is renowned worldwide for its high level of species diversity and endemism ${ }^{2}$ (mostly on the high islands of PNG, Solomon Islands, New Caledonia and Vanuatu). The region is also known to have the most extensive coral reef system in the world. Pacific islanders rely heavily on these biological resources for subsistence and for their economic, social and cultural well being. But island environments are some of the areas in which biological diversity is most threatened 
in the world. For smaller islands of the region, such as atolls, up to $75 \%$ of indigenous plant species are in danger of extinction.

Island ecosystems are described as fragile because of their generally small size and endemicity. Given the small land space, endemic species on islands can be lost within a very short time span due to introduction of insect pests, diseases, predators or destruction of critical habitat (often associated with construction activities). The loss of any habitat is likely to mean the extinction of species of plants or animals. Because of size, a large proportion of the land, its inhabitants and the adjacent sea are likely to be affected by disturbances that might be only minor regional events on a larger landmass.

\section{Unsustainable logging}

Typically, unsustainable logging describes a situation where the rate of log harvests exceeds sustainable yields, leading to the depletion of a resource. Unsustainable logging practices commonly occur in the region but are of particular concern in Solomon Islands where large scale logging operations are conducted by multinational companies, mostly taking place on customary land. To address this issue both Solomon Islands and Vanuatu have adopted codes of logging practice. However, both countries have experienced implementation difficulties either due to lack of training, monitoring and enforcement capacity, as in the case of Vanuatu, or because of generalised corruption at all levels of the decision making, a process facilitated by a rapid monetarisation of certain sectors of society and the emergence of new elites in villages. ${ }^{3}$ In addition, the issue of corruption in Solomon Islands is extremely difficult to address given the economic dependency of the country on log exports. To illustrate the current ineffectiveness of the logging regulation, in 1995 Solomon Islands set a sustainable yield for logging activities at 325,000 cubic metres per year but in that year the $\log$ exports reached 748,500 cubic metres. ${ }^{4}$

\section{Unsustainable coastal fishing}

Over-exploitation of inshore marine resources combined with the use of damaging fishing practices (using dynamite for example) and coastal pollution has caused declines in the amount of coastal fish stock. This is the case notably for rock cod (Serranidae), mullet (Mugilidae), scad (Carangidae) and mackerel (Scombridae), while some species, such as coconut $\mathrm{crabs}^{5}$ and giant clams, have been driven to extinction in several areas. The question of sustainability in the exploitation of inshore resources can be formulated in terms similar to logging. As stated by King et. al "a fish stock may be regarded as over-exploited when the numbers of fish are reduced to such an extent that the remaining adults are unable to produce enough young fish to maintain the stock."

\section{Secondary degradation because of unsustainable land use}

Degradation of land and coastal environments is now widespread throughout PICs, typically as a result of development activities that are either unsustainable by nature, as in the case of clearfell logging, or for which no environmental impact assessments (EIAs) were conducted and therefore no monitoring, mitigation or alternative 
development options were devised. The most common types of impacts from development activities include soil erosion, impacts of sedimentation on coral reefs, mangrove reclamation and degradation and pollution by sewage and industrial effluents.

\section{Erosion}

Soil erosion is a common consequence of construction projects, agriculture and forestry activities, especially on steep slopes. Poor land use practice is the most common reason for soil erosion. Soil erosion leads to poorer soil productivity and to sedimentation downstream.

\section{Sedimentation}

As mentioned before, sedimentation ${ }^{7}$ on coral reefs is usually a consequence of soil erosion and more generally of all coastal developments since almost every project generates suspended sediment (at least during the construction phase) and countries in the region are surrounded by coral. The impacts of sedimentation on coral reefs is to reduce photosynthesis of algae growing as part of their structure. In the best case scenario sedimentation will therefore inhibit coral growth. However, long term exposure to sediment will kill all or part of the coral colony. Even if the exposure does not kill the coral directly, it will reduce coral growth as energy is diverted to clearing sediment. Sediment exposure has led to 'coral bleaching', which occurs because of the loss of the algae.

\section{Mangrove degradation}

Mangrove degradation and reclamation is another issue linked to the widespread perception of mangroves as wastelands that can be used as garbage tips or for land reclamation. This view is now being challenged as the ecological role of mangroves is gradually better understood. Mangroves, as a group of trees adapted to living on the boundary of marine and terrestrial environments, play several crucial ecological functions such as slowing down water movement and aiding in sediment deposition, thus reducing sedimentation of reefs. Mangroves provide organic matter (through their leaf litter and from nutrients of river water) that supports communities of microorganisms that in turn provide food for the young fish living in the mangroves. Finally, they also provide habitats for juvenile fish species (about 60 to $80 \%$ of commercial fish species are associated with mangroves at some point in their life cycle) and for wildlife species including birds.

\section{Pollution}

Coastal pollution, due to organic and industrial effluents, is localised to urban areas. The impacts of organic effluents (sewage, fish wastes, slaughterhouse wastes and food processing wastes) are to change the receiving ecosystem by stimulating algae growth at the expense of other organisms, coral for example. This phenomenon can lead to eutrophication and ecological death when algae growth reaches such a level that the dissolved oxygen in the water is all used up by the decaying algae. Regarding 
industrial effluents, concerns can particularly be raised with toxic chemicals concentrated in the food chain, as happens with the insecticide DDT.

As can be seen, a wide range of environmental issues are of concern to the South Pacific region. In addressing these concerns a number of approaches can be taken. Introduced legal methods such as EIAs, the setting of polluting emissions standards and land use planning schemes can be used to great effect in some situations. Traditional environmental management methods in line with the realities of customary land and marine tenure may also be used to address these issues. The various approaches to addressing environmental concerns and their potential benefits and shortcomings must, however, be analysed in the light of good governance prerequisites in order to ensure that effective and appropriate responses to environmental issues are formulated.

\section{THE NATURE AND ROLE OF ENVIRONMENTAL LAW}

Environmental law first developed in western countries as a result of parliamentary activity and the adoption of statutes that broadened the scope of administrative control. In this sense, environmental law is almost entirely a product of legislation. The reason for this is that the scope and content of environmental law falls largely within the category of 'public law' rather than 'private law'. Accordingly, the emergence of environmental law in western countries coincides with the recognition by the public and the government of past mistakes and of the necessity of using the Earth's resources in a more sustainable manner. The evolution and gradual recognition of environmental law in a given country will therefore be a function of the public acceptance and awareness of non-economic as well as economic factors that are important in enhancing the quality of life to which we all aspire. In other words, the evolution and expansion of environmental law is dependant upon the extent to which the limits of conventional development models (that do not systematically incorporate non-economic parameters such as the social and environmental impacts of development schemes) are recognised.

This is translated into the incorporation of the concept of sustainable development and sustainability ${ }^{8}$ in the exploitation of resources in environmental legislation, which outlines the need to integrate conservation and development so as to ensure that the rights of future generations are not compromised.

At the national level the implementation of the concept of sustainable development raises a number of questions. How should governments change policies and priorities to reflect the concept of sustainability? How will the concept find concrete expression in law so that it is capable of being enforced? In terms of decision making there may also be practical problems in reconciling the policy objective of sustainability with development priorities and objectives. Should governments legislate to give priority to concepts of sustainability and if so how will these be legally defined and what mechanisms will be put in place to ensure coordination, continuity and compliance in decision making? This also raises the question of the relevance of using foreign 
legislative models in introducing comprehensive environmental legal reform, as the enforcement of foreign models may be of questionable practicality in the context of PICs. As Farrier puts it:

Symbolic legislation may satisfy the demands of international conventions, but legislation which is not enforced will do little to protect the environment of your South Pacific Countries. Indeed it may lead to a complacency, based on a belief that something is being done, that is positively damaging."

Further, the implementation of environmental legislation presents a number of difficulties due to commonly found reasons, such as:

- the isolation of communities, resulting in lack of awareness of laws created by the central government and lack of enforcement due to travel restrictions;

- the smallness of communities, generating difficulties in getting independent enforcement officers to apply sanctions;

- the inadequacy of penalties for environmental offences (usually relying upon the imposition of fines) and the need to find more culturally appropriate models of communal sanction against environmental offenders;

- cultural traditions of customary landowners which may be opposed to central government implementation of the law, unless a genuine participation of local and landowner in the drafting is ensured; and

- the lack of recognition of traditional methods of resource management and control in the legislation.

Further, one should bear in mind the appropriateness of foreign model legislation for addressing the actual environmental issues of the country in which environmental law reform is under consideration. ${ }^{10} \mathrm{~A}$ simple but striking example of the ineffectiveness of foreign model command and control legislation is the Anti-Litter Decree 1992 of Fiji. This decree has never been enforced and, in the absence of public information campaigns, the population remains unaware of its existence. Despite the imposition of severe penalties this piece of legislation has had little effect on curbing the litter problem in Fiji. It shows that in order to be effective, there must be an ongoing commitment to law enforcement and education of the population on the reasons for the law. Without such a commitment any piece of legislation remains largely irrelevant to the population and will therefore be largely ignored.

Another example that illustrates the difficulty of imposing foreign model legislation and institutions is the proposed Environment and Resource Management Bill in Vanuatu. This Bill is intended to facilitate the establishment of relevant institutions and mechanisms for managing the environment (pollution control, mandatory EIAs, protection of natural heritage and biodiversity conservation). A number of modified versions of this Bill have circulated amongst the various stakeholders as a number of legal experts and draftsmen succeeded each other, but after several years the Bill still has not been tabled in Parliament for consideration. Unfortunately none of the legal experts and draftsmen are aware of the issues facing Vanuatu in terms of feasible 
institutions and enforcement procedures. Therefore their work tends to rely on foreign models of legislation that appear too elaborate to be able to grasp the environmental issues and to address issues of capacity and responses to law enforcement that are specific to Vanuatu. Given the existing financial and human resource constraints to implementing introduced models of law enforcement, traditional conservation and resource management practices have the potential to bring more effective results than western models of law enforcement in the South Pacific.

In fact, one can argue that many of the environmental problems or existing gaps in the law of PICs may be resolved without enacting command and control legislation, but instead by strengthening existing institutions in government (such as the Environment Unit in Vanuatu) as well as local government or village authorities and providing community leaders with the necessary environmental awareness and education.

It is argued here that the implementation of the concept of sustainable development in the South Pacific requires first and foremost the institutional development of a society. That is, good governance and community participation in the development process itself is needed.

\section{GOOD GOVERNANCE AND CAPACITY BUILDING}

If governance is defined as the manner in which power is exercised in the management of a country's economic and social resources for development, then the linkage with sustainable development and environmental law is quite obvious, despite having been overlooked to a large extent in the good governance discourse. ${ }^{11}$ Good governance presupposes efficient administration and transparent institutions capable of meeting the requirement of accountability. To achieve this, public administration reforms are necessary. In particular priority needs to be given to the establishment of a state governed by law, the development of a judicial system and of local government autonomy and administration.

\section{Strengthening the public sector}

Public administrative reforms are leading to institutional changes in the South Pacific as in most developing countries, but whether or not these reflect the objectives of sustainable development can be questioned. One shortcoming can be readily identified in the fact that such reforms are often driven by aid donors without necessarily taking into consideration the cultural factors responsible for most cases of corruption, nor the applicability of the economic model proposed. For example, under Vanuatu's Comprehensive Reform Programme (CRP), whose establishment was part of the conditions set by the World Bank for granting further loans to the Republic of Vanuatu, a reform of the civil service has been undertaken. This reform led to a drastic reduction in the number of civil servants while increasing the salaries of senior officials to provide incentives to productivity and efficiency in the public service and to diminish the risk of corruption. Although these reforms appear 
necessary to improve the accountability of the executive, the CRP has also been criticised for its focus on privatisation (such as introducing the user pays principle as opposed to provision of essential services by the state) and corporatisation of the public sector. It has been argued that this reform promotes economic development without taking into account the interests of people in sustainable development. Instead, as what constitutes development is largely subjective, development strategies must be determined by the people themselves and adapted to their particular conditions. Similarly, the corporatisation of the public service does not take into consideration the fact that the majority of $\mathrm{Ni}$-Vanuatu people are relying on subsistence agriculture and are therefore unable to pay for the services that used to be provided by the state.

\section{Accountability and the Office of the Ombudsman}

Institutional strengthening of bodies whose specific role is to ensure the accountability and transparency of administrative decisions is also an essential component of the good governance agenda that clearly impacts upon environmental policies. For example, the Office of the Ombudsman can play a significant role in assisting environmental protection by way of the complaint procedure. The complaint procedure to the Ombudsman is a way of ensuring that public officials conduct themselves and their administration according to the law. For example, in Solomon Islands, various Ombudsman's reports to Parliament in recent years have demonstrated the inadequacies of present law and practices in the forestry sector, also questioning the legality of logging practices. ${ }^{12}$

\section{Decentralisation}

Decentralisation is often referred to as a form of government in line with the agenda of good governance as its aim is to devolve executive and legislative power to local and provincial government entities while relying on a number of good governance assumptions to achieve this goal. The first of these assumptions is that, through decentralisation, greater accountability will be achieved by ensuring public participation in decision making. Secondly, decentralisation assumes that budgeting and planning take place at the local and regional level, giving decisions makers the opportunity to take into account the specificity and aspirations of community groups and to accommodate them, thus promoting greater self-reliance. Thirdly, decision making takes place amongst groups that are more closely integrated with local communities, hence facilitating a more precise knowledge of issues amongst such groups. Fourthly, in countries of great cultural and linguistic diversity such as Solomon Islands and Vanuatu, decentralisation is meant to foster the recognition of the separate identity of groups and regions while at the same time uniting them.

Whilst discrepancies exist between the rhetoric of constitutional and legal autonomy and the actual practice of decentralisation in the South Pacific, ${ }^{13}$ the concept of devolving power to communities and allowing self determination is of great relevance in terms of environmental issues. Although devolution of power to community 
groups has only begun to be used recently in the environmental context, there are now a number of examples of the successful use of community capacity building programmes.

At the regional level, SPREP has initiated a number of projects aiming at building up the capacity of local resource owners and users to sustainably manage and develop their own marine resources (coral reefs, mangroves, seagrasses) while encouraging better coordination between government, NGOs and local communities. For example, SPREP has initiated:

- village level coral reef monitoring programmes and national training courses in coral reef monitoring methods;

- a regional training workshop on developing a permit system for the coral trade in PICs;

- community based marine protected areas workshops; and

- integrated coastal management initiatives to improve the capacity of PICs to respond to changes and threats to coastal areas and resources from urbanisation, land and marine based sources of pollution, inappropriate coastal and port development and land use practices.

\section{COMMUNITY PARTICIPATION AND CO-MANAGEMENT OF RESOURCES}

Another approach to good governance through decentralisation is to improve community participation in the allocation and use of resources through planning. An illustration of such a bottom-up approach can be found with the Community Area Resource Management Approach (CARMA) launched at the village level by the Land Use Planning Office (LUPO) (within the Ministry of Lands) in Vanuatu. This project is part of the Vanuatu Land Use Planning Project funded by AusAID to collect information on land use so as to achieve sustainable development and conservation of land resources. The aim is to first gather representatives of several villages in an area to make an inventory of their resources. Development and exploitation options are discussed and optimum areas for specific uses are identified. For example prime agricultural land is zoned across community councils. LUPO's role is to provide advice on the need to ensure sustainability of resources. If preservation is identified as the best option LUPO advises on how people can receive financial compensation. Once agreed amongst the communities involved, the local land use plan is submitted to the local government council and then to national government for approval. Maps are produced using the Vanuatu Resources Information System (VANRIS), a geographic information system containing attribute and statistical data, which combined with maps generated at any desired scale provide an excellent decision support tool for development options and are also relevant to EIAs. LUPO also runs workshops where government and local people are taught how to use VANRIS aiming at building the necessary training capacity for self-reliance in the use and maintenance of VANRIS. Unfortunately, despite the continuing existence of LUPO, 
funding for the Vanuatu Land Use Planning Project stopped in 2000, without having entirely achieved the level self-reliance that was expected in the time frame set for the completion of the project.

\section{Environmental impact assessments}

Community participation in decision making regarding development options, allocation and use of natural resources can take many forms. Whichever forms of community participation are favoured, in order to be truly effective they need to be accommodated within the legal and management tools that are required to address relatively new issues of large scale and potentially damaging and over-exploitative activities brought by technological development. A perfect example of such a legal and management tool devised in western countries for this purpose is the EIAs. ${ }^{14}$ This tool has already been adopted for use in some countries in the region and is in the process of becoming mandatory in a number of other Pacific countries. In Solomon Islands, EIA procedures are included in Part III of the 1998 Environment Act. In Kiribati, EIA procedures are included in Part III of 1999 Act to Provide for the Protection, Improvement and Conservation of the Environment of the Republic of Kiribati and for Connected Purposes. In both Fiji and Vanuatu EIAs appear as guidelines only, but their legal status is likely to change with the enactment of the Sustainable Development Bill in Fiji and the Environment and Resource Management Bill in Vanuatu, which both detail EIA procedures.

The object of an EIA process is to identify the possible risks to the environment that may result from a proposed action. This information is then used to decide whether to proceed with the action and on what conditions. The ultimate purpose of an EIA is not just to assess impacts; it is to improve the quality of decisions. EIAs not only force environmental knowledge into the policy process but also reveal the inadequacy of the decision making process caused by incomplete information. As a formal process EIAs can only be conceived and developed in societies with an effective system of government administration and where there is enough wealth to support them. This is because they require technical expertise coupled with scientific research in order to determine the nature and extent of potentially adverse environmental impacts.

Applied to the South Pacific, the EIA process necessarily requires a minimum institutional capacity that needs to be located at the appropriate level of government (whether central, provincial or local) where development and sectoral policies, programmes and projects are evaluated. To establish a formal EIA process, SPREP ${ }^{15}$ recommends three administrative levels so as to secure a minimum level of impartiality in the decision making process:

- Firstly, an environment unit to carry out the government functions of screening, scoping, reviewing and enforcing EIAs;

- Secondly, a senior body with authority over other departments to require them to adhere to environmental policies is required to make decisions about controversial projects. The suggested structure of this senior body is a commission made up of permanent secretaries or ministers from the major 
departments that influence the environment. Such a commission would be mandated to review both public and private sector projects;

- Thirdly, SPREP recommends that each government department concerned with natural resources should appoint a middle management person to ensure that the projects initiated by that department follow EIA procedures.

From a good governance perspective the EIA review process must ensure that there is sufficient evidence showing that people affected by the project have been consulted and that members of the local community understand the information contained in the environmental impact statement. In other words, community participation in development decisions must be established as a legally enforceable right.

With respect to the environmental issues described in the first part of this chapter, EIAs could address issues of soil erosion by developing mitigation measures such as erosion control practices like terracing or recommending the use of ponds to control sediment runoff around construction projects involving earth movement/ disturbance. Through the EIA process the erodability of soils in areas to be logged could also be determined and sensitive areas could be mapped out. Similarly, it is notable that the impacts of sedimentation on coral reefs can be easily monitored by establishing monitoring sites where the percentage of live cover of coral is measured, and that such a monitoring measure can be incorporated into the EIA process.

Addressing coastal pollution resulting from land based activities is also within the scope of EIAs by determining whether the receiving waters (stream, river and/or bay) can accommodate the additional nutrient load that will result from the proposed activity. The answer will depend on the amount of dilution that can be expected. For example, in the case of a river, the dilution is controlled by the volume of flow. In the case of a marine discharge, dilution will be determined by the amount of flushing, a function of the tidal range and the water currents. If there is insufficient dilution to reduce the nutrient loading to near background levels within $100 \mathrm{~m}$ of the outfall, then the EIA should recommend a sewage treatment to reduce the nutrients loading. One way of addressing this issue could be to ensure that the EIA for a proposed development that has industrial effluent describes the average chemical content of the waste, and the average and peak volumes.

Finally, the recognition of the ecological importance of mangroves can be incorporated in the scoping of sites subject to EIAs by proposing alternative sites.

\section{The use of customary approaches}

Community participation in the management of resources can also be promoted through a legal recognition of customary rules and practices adopted by communities themselves. Most countries in the South Pacific have in fact two legal systems in operation: that of customary law and that established through government legislation.

Although the relative positions of customary law and introduced law vary from country to country, it is fair to say that both systems of law are intended to be 
complementary, which is why both are generally recognised within countries constitutions. In practice though, the two systems are not always mutually supportive and tend to operate independently of each other. Yet improvements in environmental protection and resource management may be achieved through stronger links between customary practices on one hand and, on the other, processes developed under state law. There are also merits in strengthening customary law with new information and management practices designed to cope with resource options now available due to increased pressures on resources rising from things such as population growth, the introduction of a cash economy and the advent of new technologies.

In most countries in the South Pacific customary land and marine tenure systems have been maintained or restored after independence, with customary landholding being the dominant form of land ownership. ${ }^{16}$ Dispute resolution methods that take customary methods into account, including separate customary court structures, have also been established to resolve land disputes at least in the first instance. ${ }^{17}$ But despite the importance of customary land tenure, customary land law and customary dispute resolution methods are not fully treated as equal to introduced law as customary courts often remain subordinated to higher courts, which rely on introduced common law. For example, island courts in Vanuatu, which have been established to provide for customary resolution of disputes, are not effective in resolving land issues as most cases are directly appealed to the supreme court due to the lack of training of support staff and low level of competence of Justices over customary law. ${ }^{18}$ Indeed, under the Island Court Act [Cap 160] of Vanuatu the customary exercise of justice by chiefs is not recognised, despite the fact that the chief's role in maintaining social order remains important in most areas of Vanuatu, particularly where there is little police presence or control. In ensuring regulation of the environment (or, indeed, other areas of social regulation) to fail to utilise a functioning, and largely effective, system of authority seems to be a gross oversight, particularly when governments do not have the resources to commit to creating new systems of authority and regulation. Since chiefly authority is a working system acknowledged by all why treat it as an alternative system of justice and not fully incorporate the chiefly system of justice into the judicial system, at least in so far as land and natural resource issues are concerned?

The option of utilising traditional systems of justice for regulation of the environment has been fully explored in Samoa through the adoption of village by-laws for managing inshore marine resources. It has been such a success that the feasibility of transposing this model to other PICs is currently debated within regional forums and conferences. By-laws for the conservation of inshore fisheries were introduced in Samoa as a result of a drastic decline in catches due to over-exploitation and the use of destructive fishing methods. This situation raised alarm not only within the Fisheries Division but in a number of villages. Village fono or councils of chiefs first started to use local media to advertise village rules in order to prevent further decline of fishery resources. Advertisements focused on banning the use of explosives, 
chemicals and other destructive fishing methods and the prohibition of fishing in designated areas. These advertisements also indicated penalties to be paid to village fono for any breach of their village rules by their own residents. Any breach committed by people who were not residents of the village was subject to threats of litigation. However, as some village rules contradicted existing laws, several fono could not pursue court action against breaches by neighbouring villages. ${ }^{19}$

While the value of such a campaign to improve the conservation and management of inshore fisheries was acknowledged by the Fisheries Division, the necessity of giving legal recognition to the rules set by the village fono in the introduced courts and to ensure that such rules to do not contradict provisions of national fisheries legislation was also realised..$^{20} \mathrm{~A}$ consultation process was then initiated between representatives of village fonos and the Fisheries Division on the appropriateness of their proposed rules. This consultation process has now been formalised as the second step in the formulation of any village by-law, followed by a final check and clearance by the Office of the Attorney General. Every by-law is signed by the Director of the Ministry of Agriculture, Forest and Fisheries and Meteorology, and then passed to the Legislative Assembly to be gazetted while also being published by the Fisheries Division in the local newspaper and copies distributed in neighboring villages. As a result, the Fishery Act 1988 gives legal recognition to village by-laws and details procedures upon which a village can declare its own rules as by-laws. By-laws apply to all citizens equally, and cover any measure assisting the management and conservation of inshore fishery resources, including:

- restriction on sizes of fish and shellfish that can be taken;

- bans on certain types of fishing gear and methods;

- allocation of fish quotas;

- restriction of mesh sizes for nets and fish traps; and

- closure of fishing seasons or areas to allow fish to reproduce.

The main advantage of village by-laws over the regular laws is that the rules are created by the people with a real interest in the management and the conservation of fishery resources. This means that the village fono is more inclined to monitor and enforce such rules. Communities either build watch houses, maintain patrol canoes or employ watchmen to monitor illegal activities in their coastal zones and marine protected areas. Customary fines (the provision of pigs and taro for example) are imposed on residents of villages that own the by-laws while legal action can be taken against any breach by outsiders.

The success of the village by-law model in Samoa is therefore linked to community participation in the management of resources based on customary ownership. This model integrates one of the most important yet easily forgotten aspects of development: culture, as reflected in customary land and marine tenure systems.

The transposability of the Samoan village by-law model will be determined by the extent to which customary law is given legal recognition in the country considered 
and the extent to which the cultural and social of customary practices have been maintained in society generally. In much the same manner such by-laws should be a success in other PICs, provided that the system of custom is utilised in the same way as in the Samoan context.

Transposing the Samoan village by-law model to Melanesian countries may present additional difficulties due to the greater cultural and linguistic diversity and the erosion, in some parts of Vanuatu and the Solomon Islands, of the chiefly system and the questioning of chiefly decisions and authority. This difference may be explained by the homogenous character of Polynesian societies, both ethnically and geographically, in contrast with Melanesian countries.

A parallel to Samoa's by-laws regime can be made with the Decentralisation and Local Government Regions Act adopted by the Vanuatu Parliament in 1994, which allows the introduction of by-laws whose function is to "outline create and draw up regulations governing the environmental protection zones (natural parks, natural reserves or tourist attraction areas in the national interest)" under section 20(9) of the Act. Such by-laws designate protected areas on the basis of custom, amenity and livelihood. Customary tenure is strengthened by making it an offence to contravene the rules governing a protected area while the term of the by-laws is specified by the landowners. In addition amendments may be made by landowners at any time. Finally, under this by-law model, for every declared protected area a committee of management is set up representing both landowner interests and community interests through chiefly representation. ${ }^{21}$ However, compared with the Samoan village by-law model now applied in at least 54 villages on Upolu Island, the Vanuatu model has hardly been applied by local governments. One reason may be the focus on protected areas designation as opposed to management of resources. Another reason may be the ineffectiveness of local government structures. In addition, whereas the Samoan legislation was created because communities were already making by-laws and these needed legal recognition, the Vanuatu legislation has been drafted by law makers with little awareness by and little commitment from communities.

With an improved approach to community participation the situation may be different, as demonstrated by the co-management approach recently adopted by the Vanuatu Fisheries Department for the Trochus Niloticus combining traditional management methods with fisheries management regulation and wild stock enhancement using hatchery reared trochus juveniles. Co-management means a cooperative approach between communities, acting in their local interests, and governments, acting in the national or public interest, in the management of a particular resource. In a co-management context, the central government (in this case the Fisheries Department) acts as the coordinator and provider of technical advice, but the process should be owned by the community and be based on traditional and customary practices.

As Amos notes "customary law in Vanuatu dictates that most near-shore areas especially coral reef flats owned by clans or larger communal groups are not open to access fisheries". ${ }^{22}$ Such areas are therefore currently managed through traditional 
restrictions imposed by the resource owners including limited entry, closed seasons and restricted harvests. Again, as Amos points out, the major feature of customary tenure is that controls are expected at a local level, not from fisheries officers considered as outsiders. This gives rise to the main difficulty of combining traditional management practices and fisheries management regulations - establishing a working relationship between the Fisheries Department (as outsiders) and the resource users and owners. This relationship must necessarily take into account the need to devise income generating alternatives for communities who are depending heavily on the depleted resources concerned. As $\mathrm{Amos}^{23}$ concludes, if the people are not provided with alternatives that will ensure that their subsistence and financial needs are met, they will continue to over-exploit the resources concerned, regardless of management controls.

The advantage of co-management is that it combines scientific methods of fisheries management when sufficient data exists for it to be workable and when relevant, with traditional practices of resource exploitation. Fishing communities in turn acquire a better understanding of fisheries management principles. The costs of enforcement and management are minimised as well as the social and political conflicts between the government and the community.

\section{CONCLUSION}

This chapter explored current environmental issues in the South Pacific and possible ways of addressing them by giving meaning to two concepts commonly found in aid policies: sustainable development and good governance. Strengthening the rule of law and government institutions and introducing environmental law reforms are certainly relevant and necessary to address these issues from a top-down perspective of management. From a bottom-up perspective however, improved community participation in development decisions and the legal recognition of customary resource management practices are the most culturally appropriate and the most costefficient ways of addressing the limitations and shortcomings of the state and of promoting greater self-reliance. This approach is extremely relevant today given the increasingly limited powers granted to the state in the context of the globalised economy. Yet, reliance on these elements of a bottom-up approach to sustainable development and good governance necessitate access to education, both formal and vocational, a prerequisite that has received too little attention in the South Pacific beyond the training of future elites who tend to lose connection with the needs of their communities as they become the main beneficiaries of globalisation. Hence, before sustainable development and good governance can become truly meaningful concepts in the Pacific region, environmental education and subsequent wider consciousness of environmental issues needs to be established. 


\section{ENDNOTES}

2 The term 'endemism' refers to living species whose distribution is to be found within a specific geographical area.

3 For a discussion on the issue of corruption in the Solomon Islands forest industry see Kabutaulaka, T. 2000. Rumble in the jungle: land, culture and (un) sustainable logging in the Solomon Islands. In Hooper, A. ed. Culture and Sustainable Development in the Pacific. Canberra: National Centre for Development Studies, Australian National University. p 88-97.

4 Kabutaulaka, T. 2000. above, n 2.

5 Although coconut crabs can be considered as land-based species once they reach mature age, juveniles stay close to the water, and gradually develop their own shell and become more like land animals. As they grow they move further inland away from the coast. This species is omnivorous and forages along beaches and over coral rocks looking for food. Since harvesting takes place along the seashore (during the day coconut crabs hide in holes in the sand or under coconut trees and shrubs) it is relevant to include this species in any discussion on over-exploitation of coastal resources in the Pacific region. For additional information see: http://www.spc.org.nc/coastfish/Countries/CookIslands / MMR/7Somespecies/Ccrab.htm (Accessed 26/9/01).

6 King, M. Faasili, U. and Ropeti, E. 1995. Management Strategies for Inshore Fisheries in Tropical Pacific Islands. In Workshop Proceedings on the Management of South Pacific Inshore Fisheries, Noumea, New Caledonia, 26 June-7 July 1995, volume II. Noumea: FFA/SPC. p 510 .

7 Sedimentation is to be understood as the deposition of eroded soil materials suspended in water bodies. Sedimentation takes place when water velocity falls below a point at which the suspended particles can be carried.

8 The concept of sustainability defined by the International Union for the Conservation of Nature (IUCN) in the World Conservation Strategy published in 1980 links the maintenance of ecological processes and life support systems to the sustainable utilization of resources and the maintenance of genetic diversity. International Union for Conservation of Nature. 1980. World conservation strategy : living resource conservation for sustainable development Switzerland: IUCN.

9 Farrier, D. 1993. Introduction to Basic Concepts of Environmental Law. In Boer, B.,ed. Strengthening Environmental Legislation in the Pacific Region: Workshop Proceedings Samoa: SPREP/UNEP, p 41.

10 For further discussion on this issue, see Hewison, G. 1997. Environmental Law Reform in Vanuatu: The Challenges Facing a Small Island Developing Country. Asia Pacific Journal of Environmental Law 2(1): 27-38.

11 A notable exception is found in Ginther, K. Denters, E. \& de Waart, P. (eds.) 1995. Sustainable Development and Good Governance. Dortrecht: Martinus Nijhoff Publishers.

12 See Boer, B. 1993. Strengthening Environment Management Capabilities in Pacific Island Developing Countries. Samoa: SPREP. p 79-99.

13 It is not within the scope of this chapter to embark upon a detailed analysis of the failures of decentralisation policies in the South Pacific. Breifly the criticism here is that while in theory there are good grounds to keep decentralisation within the good governance 
agenda, its practical implementation falls short because of the failure to consider the changing life style aspirations of local communities and to enhance their capacity to make the informed choices about possible development options. In other words, devolution of power remains within the context of a top-down approach, which forgets to equip local communities with the capacity to become self-reliant the beyond traditional activities of subsistence economy.

14 Gilpin provides the following definition for an EIA: "the critical appraisal of the likely effects of a policy, plan, program, project or activity on the environment. To assist the decision-making authority, assessments are carried out independently of the proponent, who may have prepared an environmental impact statement. The decision making authority may be a level of government (local, state) or a government agency. Assessments take account of any adverse environmental effects on the community; any environmental impact on the ecosystem of the locality; any long term or cumulative effects on the environment". See Gilpin, A. 2000. Dictionary of Environmental Law. London: Edward Elgar. p 96.

15 South Pacific Regional Environment Program. 1993. A Guide to EIA in the South Pacific. Samoa: SPREP.

16 In Samoa, about 80 percent of land is customary land. Samoa's Constitution formalised the existence of three categories of land: customary, freehold and public land (Article 101(1)). Article 101(2) of the Samoan Constitution provides that customary land is held in accordance with Samoan custom and usage and with the law relating to Samoan custom and usage. In the Solomon Islands, about $87 \%$ of land is under customary ownership. In Fiji, 83 percent of land is classified as "native land" meaning that it is owned by indigenous Fijians.

17 Article 53 of the Constitution of Vanuatu provides that "parliament shall provide for the establishment of village or island courts with jurisdiction over customary matters and shall provide for the role of chiefs in such courts".

18 For further discussion on the role and effectiveness of Island Courts in Vanuatu, see Jowitt, A. 2000. Island Courts in Vanuatu. School of Law Occasional Paper Series Volume 2. Vanuatu: University of the South Pacific.

19 See Fa'asili \& Mulipola, A. 1999. The Use of Village By-Laws in Marine Conservation and Fisheries Management. In First Heads of Fisheries Meeting, Pacific Community, Noumea, New Caledonia, 9-13 August 1999 Noumea: SPC.

20 Fa'asili \& Mulipola, A. 1999. Above, n 18.

21 see Hunt, C. 1997. Cooperative Approaches to Marine Resources Management in the South Pacific. In Larmour, P. ed. The Governance of Common Property in the Pacific Region. Canberra: Asia Pacific Press. p 145-164.

22 This means that such resources can only be harvested by members of the clan. See Amos, M. 1995. Combination of Fisheries Management Regulation, Traditionally Based Management and Wild stock Enhancement using Hatchery Reared Trochus Juveniles as Precautionary Management Principle for Trochus Niloticus Resources in Vanuatu. In Workshop Proceedings on the Management of Pacific Inshore Fisheries, Noumea, New Caledonia, 26 June-7 July 1995, volume II. Noumea: FFA/SPC. p 169-179. 